\title{
The Effective Injection Zone at the Popliteal Crease for Tibial and Common Peroneal Nerve Blocks and its Relation with the Origin Point of the Medial and Lateral Sural Cutaneous Nerves
}

\author{
Zona de Inyección Eficaz en el Pliegue Poplíteo para el Bloqueo de los Nervios Tibial y Fibular \\ Común y su Relación con el Punto de Origen de los Nervios Cutáneo Sural Medial y Lateral
}

Lei Zhong*; Jincheng Wang*; Hongjuan Fang*; Yanguo Qin*; Jianlin Zuo* \& Zhongli Gao*

ZHONG, L.; WANG, J.; FANG, H.; QIN, Y.; ZUO, J. \& GAO, Z. The effective injection zone at the popliteal crease for tibial and common peroneal nerve blocks and its relation with the origin point of the medial and lateral sural cutaneous nerves. Int. J. Morphol., 32(1):79-83, 2014.

SUMMARY: A popliteal nerve block may be used to provide anesthesia and extended analgesia of the lower extremity, to ameliorate severe and long lasting postoperative pain. The aim of this study was to elucidate the anatomical location of tibial (TN) and common peroneal (CPN) nerves in the popliteal crease for effective nerve block. Fifty fresh specimens from 27 adult Chinese cadavers (16 males and 11 females, age range from 35 to 87 years) were investigated. Twenty-two cadavers were used to identify nerve locations and 5 cadavers were used to determine the depths of nerves in cross section. TN was found to be located at 50\% from the most lateral point of the popliteal crease at $1.4 \mathrm{~cm}$ deep to the surface. In $20 \%$ of the 50 specimens, the medial sural cutaneous nerve branched out below or at the popliteal crease, whereas the CPN was located at $26.0 \%$ from the most lateral point of the popliteal crease and at $0.7 \mathrm{~cm}$ deep to the surface. Furthermore, in $6.0 \%$ of specimens the lateral sural cutaneous nerve branched out below or at the popliteal crease. This study suggests that the TN and CPN leave the sciatic nerve at variable distances from the popliteal crease. However, we believe that the results of the present study about the location of TN and CPN at the popliteal crease offer a good guide to optimal nerve block.

KEY WORDS: Tibial nerve; Common peroneal nerve; Nerve block; Anatomy.

\section{INTRODUCTION}

A popliteal nerve block (PNB) is often used during surgery and to treat spasticity below the knee (Saleh et al., 2009; Taboada Muñiz et al., 1993). Two approaches are used for PNB, namely, the classical and intertendinous approaches. The classical approach is frequently used for PNB and involves inserting the needle $7 \mathrm{~cm}$ above the popliteal crease and $1 \mathrm{~cm}$ lateral to the midline of the popliteal fossa triangle ( Hadzic et al., 2002). On the other hand, the intertendinous approach involves injection at the midpoint between the tendons of the biceps femoris and the semitendinosus. Some studies have concluded that the intertendinous approach is the more useful of the two (Hadzic et al.; Nader et al., 2009). These two approaches to injections at the sciatic nerve are referred to collectively as prebifurcation blocks. However, some papers (Buys et al., 2010; Paqueron et al., 1999) reported that blocking the TN and CPN separately provides a faster onset than a prebifurcation block.
The PNB is usually injected under ultrasound (US) guidance in clinical practice and several studies have described the merits of US imaging (McCartney et al., 2004; Sinha \& Chan, 2004; Robards et al., 2009). Bruyn \& Schmidt (2009) reported that US-guided injections produce significantly better clinical outcomes than blind injections. However, the US-guided injections require the coordination of both hands.

Moreover, sometimes surgeons must make a blind injection in clinical practice, and both blind injection and US-guided injection do not take into account anatomical variations of the sciatic nerve. Thus, incomplete block of the sciatic nerve in the popliteal fossa cannot be disregarded (Saleh et al.; Nader et al.; Vloka et al., 2001). Accordingly, an anatomical study is required on the location of the SN in the popliteal fossa and popliteal crease.

* Department of Orthopedics, China-Japan Union Hospital of Jilin University, ChangChun, China. 
Muscular spasticity in the lower limb is an associated issue, and is common in post-stroke patients. Spasticity in lower limbs is a condition that frequently complicates stroke, and not only interferes with lower extremity function and limits daily activities, but can also cause musculoskeletal complications. However, detailed knowledge is required for selective neurolysis, which must be made as near as possible to the extramuscular nerve branching in order to better select the nerve branches that supply the muscles involved in spasticity (Lepage et al., 2005). Some anatomical studies have been conducted to determine the locations of nerves to leg muscles (tibialis posterior, peroneus) (Lee et al., 2011a, 2001b). Saleh et al. and Vloka et al. investigated the location of the $\mathrm{SN}$ in the popliteal fossa, but these studies produced different results regarding the location of the TN and CPN bifurcation in the popliteal fossa. Furthermore, the depth and the location of the nerves passing on popliteal crease were not measured in these studies.

Other nerves also branch out at the popliteal fossa, namely, the medial (MSCN) and lateral sural cutaneous nerve (LSCN). These nerves are the major sensory nerves in the lower limb (Ikiz et al., 2005). Knowledge of anatomic correlations between the origins of the SN, TN, and CPN are important when performing selective block, but information on this topic is limited.

Accordingly, the aim of this study was to elucidate the anatomical location of these nerves in the popliteal crease for effective nerve block.

\section{MATERIAL AND METHOD}

Fifty fresh specimens from 27 adult Chinese cadavers (16 males and 11 females, age range from 35 to 87 years) were investigated. Cases with pathological changes or leg trauma were excluded. Twenty-two cadavers were used to identify nerve locations and 5 cadavers were used to determine the depths of nerves in cross section.

Dissection. An incision was made the popliteal fossa area on the posterior surface. After removing the skin around the popliteal fossa, the SN was exposed completely and dissected carefully to identify related structures surrounding the popliteal fossa (Fig. 1). Cadavers were placed in the anatomical position during dissection and measurement. We often sprayed water on donated samples during dissection to prevent drying out.

Measurements. Five-variables were measured in this study, three of which were as follows (Fig. 2):
1. The prebifurcation point of the TN and CPN on the SN.

2. The point where the TN passes the popliteal crease.

3. The point where the CPN passes the popliteal crease.

These parameters were measured in relation to the popliteal crease on the surface. Variable Nos. 2 and 3 were measured from lateral to medial on the popliteal crease. The remaining two variables were (Fig. 2):

4. The point of origin of the MSCN from the TN.

5. The point of origin of the LSCN from the CPN

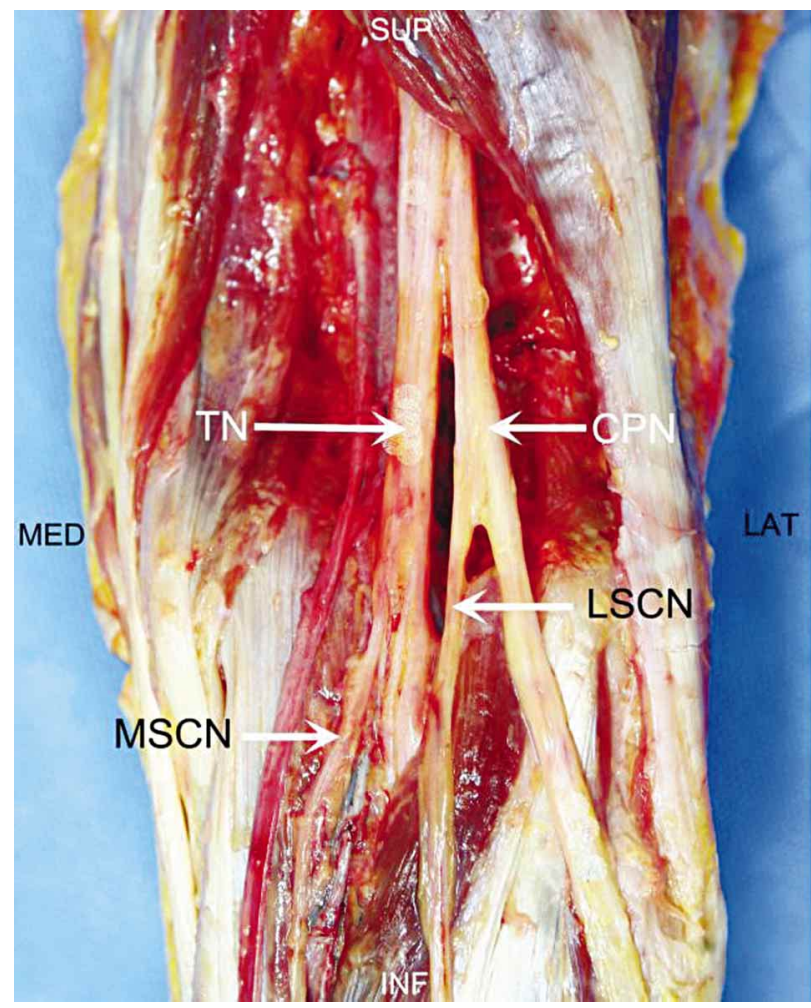

Fig. 1. Photographs of the posterior aspect showing nerve conformance with the popliteal fossa. TN: tibial nerve, $\mathrm{CPN}$ : common peroneal nerve, MSCN: medial sural cutaneous nerve, SCN: lateral sural cutaneous nerve. MED: medial, LAT: lateral, SUP: superior, INF: inferior.

These two variables were measured using $\mathrm{x}$ and $\mathrm{y}$ coordinates. The $\mathrm{x}$ axis defined as the line from the most lateral point of the popliteal crease that transected the y axis perpendicularly. The y axis was defined as the line from the measurement point that transected the $\mathrm{x}$ axis perpendicularly. Transverse sections of the popliteal crease were prepared from 10 limbs (5 cadavers), and the depth of the sciatic nerve from skin was measured.

All data were analyzed using SPSS version 15.0 (SPSS Inc., Chicago, IL). Comparisons between males and females were performed using the t-test. $\mathrm{P}$ values of $<0.05$ were considered significant. 


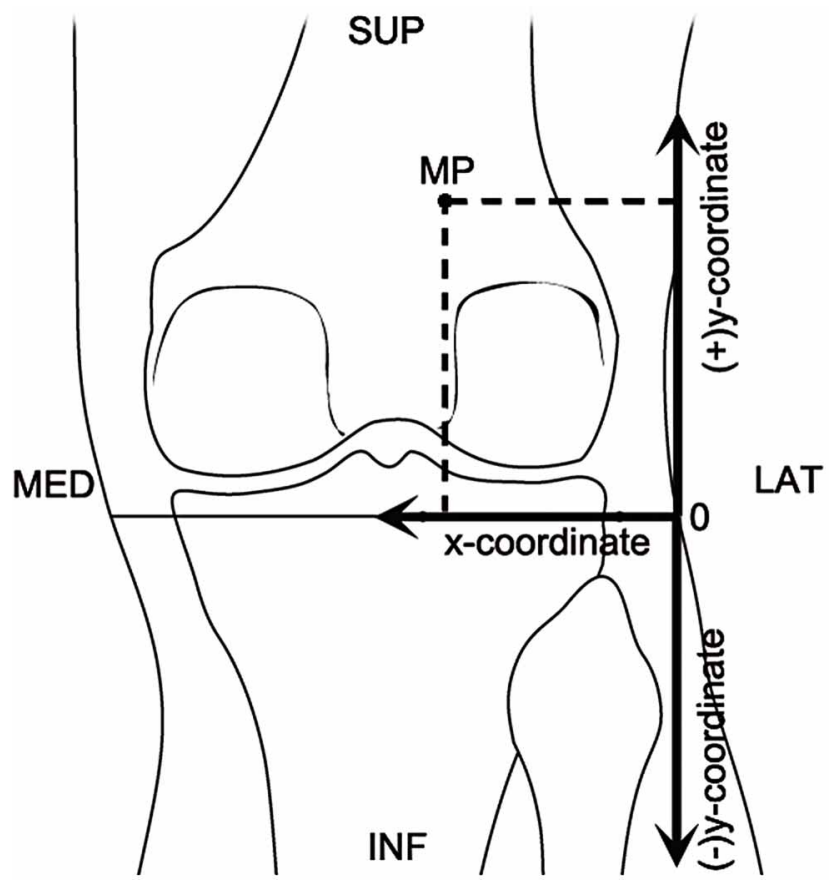

Fig. 2. Drawing showing the reference line and the methods of measurement. MP: measurement point, LAT: lateral, MED: medial, SUP: superior, INF: inferior.

\section{RESULTS}

The mean length of the popliteal crease as a reference line was $11.0 \pm 1.1 \mathrm{~cm}$. The prebifurcation point of the $\mathrm{SN}$ from the popliteal crease was $7.9 \pm 2.6 \mathrm{~cm}$. No significant difference was observed between the 5 variables in males and females.

The location of TN and CPN at the popliteal crease. The point where the TN passed the popliteal crease was $5.5 \pm 0.5 \mathrm{~cm}(50.0 \pm 8.0 \%)$ and the point where the CPN passed the popliteal crease was $2.9 \pm 0.8 \mathrm{~cm}$ $(26.0 \pm 6.0 \%)$ (Fig. 3).

The origin of the sural nerve. The origin of the MSCN was $5.2 \pm 1.1 \mathrm{~cm}(48.0 \pm 10.0 \%)$ from $\mathrm{TN}$ on the $\mathrm{x}$ axis and $1.1 \pm 1.8 \mathrm{~cm}$ on the $y$ axis. The large standard deviation of the $y$ coordinate was caused by branched out below the popliteal crease in 7 cases; the average value of these samples, branched out below the popliteal crease, was $-1.9 \mathrm{~cm}$. Furthermore, in one case has not branched out the sural nerve from the TN.

The point of origin of the $\mathrm{LSCN}$ from the $\mathrm{CPN}$ was $3.3 \pm 0.9 \mathrm{~cm}$ $(30.0 \pm 8.0 \%)$ on the $\mathrm{x}$ axis and $2.0 \pm 1.9 \mathrm{~cm}$ on $\mathrm{y}$ axis. The standard deviation of the y coordinate was high because in two cases branching occurred below the popliteal crease. The average value of these 2 samples was $-3.7 \mathrm{~cm}$. Forty-nine of the 50 samples showed branching out of at least $1 \mathrm{LSCN}$.

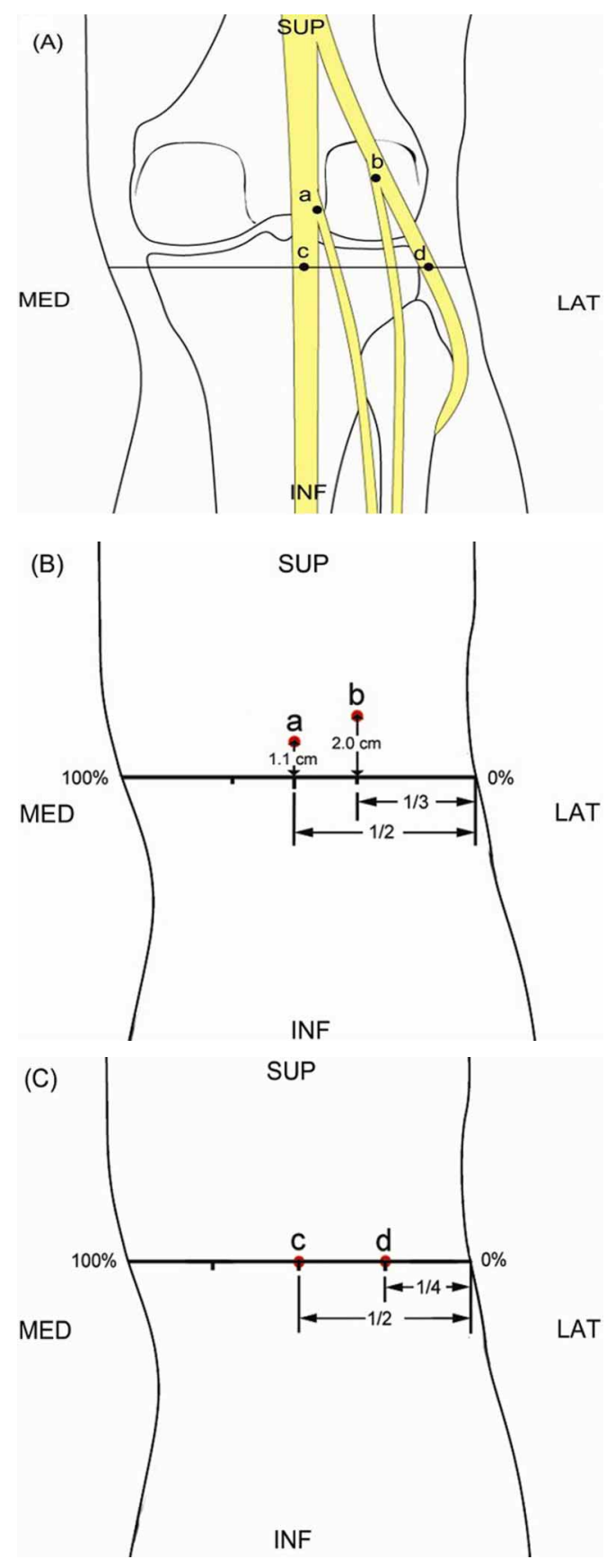

Fig. 3. (A) (B) (C). Division of the sciatic nerve in the popliteal fossa. Transverse line on the figure: popliteal crease. (A)a,(B)a: The origin point of MSCN from TN was $5.2 \pm 1.1 \mathrm{~cm}(48.0 \pm 10.0 \%)$ on $\mathrm{x}$ coordinate and $1.1 \pm 1.8 \mathrm{~cm}$ on y coordinate. (A)b, (B)b: The origin point of LSCN from $\mathrm{CPN}$ was $3.3 \pm 0.9 \mathrm{~cm}(30.0 \pm 8.0 \%)$ on $\mathrm{x}$ coordinate and $2.0 \pm 1.9 \mathrm{~cm}$ on y coordinate. $(\mathrm{A}) \mathrm{c},(\mathrm{C}) \mathrm{c}$ : The point where $\mathrm{TN}$ passes the popliteal crease was $5.5 \pm 0.5 \mathrm{~cm}(50.0 \pm 8.0 \%)$. (A)d, (C)d: The point where CPN passes the popliteal crease was $2.9 \pm 0.8 \mathrm{~cm}(26.0 \pm 6.0 \%)$. MSCN: medial sural cutaneous nerve, LSCN: lateral sural cutaneous nerve, TN: tibial nerve, CPN: common peroneal nerve. MED: medial, LAT: lateral, SUP: superior, INF: inferior. 
The exception showed branching out of two sural nerves with $\mathrm{x}$ and $\mathrm{y}$ coordinates of $<1 \mathrm{~cm}$ of each other (Fig. 3).

The depths of nerves. The depths of the TN and CPN at the popliteal crease were measured in posterior aspect. The CPN was located at a depth of $0.7 \pm 0.2 \mathrm{~cm}$ (max: 0.94, min: 0.50 ) from the surface on popliteal crease, whereas the TN was located at a depth of $1.4 \pm 0.2 \mathrm{~cm}$ (max: 1.7, min: 1.2).

\section{DISCUSSION}

Previous cadaver dissection studies have reported that the bifurcation of the SN occurs at variable distances from the popliteal crease (Saleh et al.; Vloka et al.) According to Vloka et al. the mean distance above the popliteal crease at which the sciatic divides is $6.1 \pm 2.7 \mathrm{~cm}$; however, distances varied widely, from 0 to $11.5 \mathrm{~cm}$. Others have reported that the sciatic nerve divides at $8.1 \mathrm{~cm}$ (range 5.0 to $18.0 \mathrm{~cm}$ ) from the popliteal crease (Saleh et al.) In the present study, this was found to occur at $7.9 \pm 2.6 \mathrm{~cm}$ ( $\mathrm{min}: 4.0 \mathrm{~cm}$, max: $12.0 \mathrm{~cm}$ ). The mean distance above the popliteal crease at which the sciatic divided in the present study is similar to that found by Saleh et al. in the Saudi Arabian population.

Buy et al. demonstrated that separate nerve blocks of the TN and CPN distal to the point of bifurcation of the $\mathrm{SN}$ in the popliteal fossa takes significantly less time than a prebifurcation SN block. In the present study, we measured the locations of these two nerves at the popliteal crease, and we found that the location of $50 \%$ from the lateral point of popliteal crease for TN and $26 \%$ for CPN (Fig. 3).
Moreover, CPN and TN were found to be $0.7 \pm 0.2$ $\mathrm{cm}$ and $1.4 \pm 0.2 \mathrm{~cm}$ deep to the surface, respectively, which is helpful information when separate injections are required.

The location of the sural nerve at the popliteal fossa has been investigated twice (Ikiz et al.; Mestdagh et al., 2001). In the study conducted by Ikiz et al., the LSCN was found to be absent in $16.7 \%$ of specimens and the MSCN to be absent in only $6.7 \%$ of specimens. In the study by Mestdagh et al. the LSCN was found to be absent in $19.0 \%$ of specimens and the MSCN in only $2.7 \%$ of specimens. In the present study, the LSCN was not found to be absent in any case, instead in 1 of the 50 specimens, 2 LSCNs branched out and the MSCN was absent in one case. These variations could be the result of racial differences or due to the small number of specimens studied.

Mestdagh et al. reported that the origin points of the MSCN and the LSCN were 6.6 and $5.7 \mathrm{~cm}$ below the bifurcation of the SN trunk. These results cannot be compared with ours because of the different reference point used. We measured distances from the popliteal crease using $\mathrm{x}$ and $\mathrm{y}$ coordinates to identify the exactly locations of nerves (Fig. 2).

Summarizing, on our fifty specimens the TN was found to be located at $50 \%$ from the most lateral point of the popliteal crease at $1.4 \mathrm{~cm}$ deep to the surface. In $20 \%$ of the 50 specimens, the MSCN branched out below or at the popliteal crease, whereas the $\mathrm{CPN}$ was located at $26.0 \%$ from the most lateral point of the popliteal crease and at $0.7 \mathrm{~cm}$ deep to the surface. Furthermore, in $6.0 \%$ of specimens the LSCN branched out below or at the popliteal crease. We believe that the results of the present study offer a good guide to optimal nerve block (Fig. 3).

ZHONG, L.; WANG, J.; FANG, H.; QIN, Y.; ZUO, J. \& GAO, Z. Zona de inyección eficaz en el pliegue poplíteo para el bloqueo de los nervios tibial y fibular común y su relación con el punto de origen de los nervios cutáneo sural medial y lateral. Int. J. Morphol., 32(1):79-83, 2014.

RESUMEN: El bloqueo nervioso poplíteo puede ser utilizado para proporcionar anestesia y analgesia prolongada del miembro inferior y para aliviar el dolor postoperatorio severo y duradero. El objetivo fue determinar la localización anatómica de los nervios tibial (NT) y fibular común (NFC) en el pliegue poplíteo para un bloqueo nervioso efectivo. Se utilizaron 50 miembros inferiores frescos pertenecientes a 27 cadáveres adultos chinos (16 hombres y 11 mujeres, rango de edad entre 35-87 años). Se utilizaron 22 cadáveres para identificar la localización de los nervios y los 5 restantes para determinar la profundidad de los nervios en una sección transversal. El NT se encontró en el 50\% de los casos desde el punto más lateral del pliegue poplíteo a 1,4 cm de la superficie. En el $20 \%$ de 50 muestras, el nervio cutáneo sural medial se ramificó por debajo o en el pliegue poplíteo, mientras que el NFC se encontró en el $26 \%$ de los casos desde el punto más lateral del pliegue poplíteo a $0,7 \mathrm{~cm}$ de la superficie. Además, en el $6 \%$ de las muestras, el nervio cutáneo sural lateral se ramificó por debajo o en el pliegue poplíteo. Nuestros resultados sugieren que el NT y NFC emergen del nervio ciático a distancias variables del pliegue poplíteo. Creemos que los resultados sobre la ubicación de NT y NFC en el pliegue poplíteo ofrecen una buena guía para el adecuado bloqueo nervioso.

PALABRAS CLAVE: Nervio tibial; Nervio fibular común; Bloqueo nervioso; Anatomía. 


\section{REFERENCES}

Bruyn, G. A. \& Schmidt, W. A. How to perform ultrasound-guided injections. Best Pract. Res. Clin. Rheumatol., 23(2):269-79, 2009.

Buys, M. J.; Arndt, C. D.; Vagh, F.; Hoard, A. \& Gerstein, N. Ultrasound-guided sciatic nerve block in the popliteal fossa using a lateral approach: Onset time comparing separate tibial and common peroneal nerve injections versus injecting proximal to the bifurcation. Anesth. Analg., 110(2):635-7, 2010.

Hadzic, A.; Vloka, J. D.; Singson, R.; Santos, A. C. \& Thys, D. M. A comparison of intertendinous and classical approaches to popliteal nerve block using magnetic resonance imaging simulation. Anesth. Analg., 94(5):1321-4, 2002.

Ikiz, A. A.; Ucerler, H. \& Bilge, O. The anatomic features of the sural nerve with an emphasis on its clinical importance. Foot Ankle Int., 26(7):560-7, 2005.

Lee, J. H.; Lee, B. N.; An, X.; Chung, R. H. \& Han, S. H. Location of the motor entry point and intramuscular motor point of the tibialis posterior muscle: for effective motor point block. Clin. Anat., 24(1):91-6, 2011a.

Lee, J. H.; Lee, B. N.; An, X.; Chung, R. H.; Kwon, S. O. \& Han, S. H. Anatomic localization of motor entry point of superficial peroneal nerve to peroneus longus and brevis muscles. Clin. Anat., 24(2):232-6, 2011b.

Lepage, D.; Parratte, B.; Tatu, L.; Vuiller, F. \& Monnier, G. Extraand intramuscular nerve supply of the muscles of the anterior antebrachial compartment: applications for selective neurotomy and for botulinum toxin injection. Surg. Radiol. Anat., 27(5):420-30, 2005.

McCartney, C. J.; Brauner, I. \& Chan, V. W. Ultrasound guidance for a lateral approach to the sciatic nerve in the popliteal fossa. Anesthesia, 59(10):1023-5, 2004.

Mestdagh, H.; Drizenko, A.; Maynou, C.; Demondion, X. \& Monier, R. Origin and make up of the human sural nerve. Surg. Radiol. Anat., 23(5):307-12, 2001.

Nader, A.; Kendall, M. C.; Candido, K. D.; Benzon, H. \& McCarthy, R. J. A randomized comparison of a modified intertendinous and classic posterior approach to popliteal sciatic nerve block. Anesth. Analg., 108(1):359-63, 2009.

Paqueron, X.; Bouaziz, H.; Macalou, D.; Labaille, T.; Merle, M.; Laxenaire, M. C. \& Benhamou, D. The lateral approach to the sciatic nerve at the popliteal fossa: One or two injections? Anesth. Analg. 89(5):1221-5, 1999.

Robards, C.; Hadzic, A.; Somasundaram, L.; Iwata, T.; Gadsden, J.; Xu, D. \& Sala-Blanch, X. Intraneural injection with low- current stimulation during popliteal sciatic nerve block. Anesth. Analg., 109(2):673-7, 2009.

Saleh, H.A.; El-fark, M. M. \& Abdel-Hamid, G. A. Anatomical variation of sciatic nerve division in the popliteal fossa and its implication in popliteal nerve blockade. Folia Morphol. (Warsz), 68(4):256-9, 2009.

Sinha, A. \& Chan, V. W. Ultrasound imaging for popliteal sciatic nerve block. Reg. Anesth. Pain Med., 29(2):130-4, 2004.

Taboada Muñiz, M.; Álvarez, J.; Cortés, J.; Rodriguez, J. \& Atanassoff, P. G. Lateral approach to the sciatic nerve block in the popliteal fossa: Correlation between evoked motor response and sensory block. Reg. Anesth. Pain Med., 28(5):450-5, 2003.

Vloka, J. D.; Hadzic, A.; April, E. \& Thys, D. M. The division of the sciatic nerve in the popliteal fossa: Anatomical implications for popliteal nerve blockade. Anesth. Analg., 92(1):215-7, 2001.

\section{Correspondence to:}

Gao Zhong li, M.D., Ph.D.

Department of Orthopedics

China-Japan Union Hospital of Jilin University

No. 126 of XianTai Street, 130033, Changchun CHINA

TEL: +86-431-8878-2768

FAX: +86-431-8878-2768

Email: gaozhongli99@gmail.com

Received: 19-02-2013

Accepted: 19-11-2013 